\title{
Concrete propensity to fire spalling: testing and observations
}

\author{
Izabela Hager $^{1}$, Katarzyna Mróz ${ }^{1, *}$, and Tomasz Tracz ${ }^{1}$ \\ ${ }^{1}$ Cracow University of Technology, Warszawska St. 24, Cracow 31-155, Poland
}

\begin{abstract}
This article presents results of fire spalling tests on small concrete slabs and studies of material parameters that may increase its occurrence. Experimental techniques enabling to study and determination of material features are presented and discussed. Experimental studies on spalling behaviour of elements were carried out on seven different concrete mixes with constant content of cement paste and mortar. Research aimed at determining influence of the following parameters: w/c ratio $(0.30 ; 0.45$; 0.60), cement type (CEM I, CEM III) and type of aggregates (riverbed gravel, granite, basalt) on fire concrete spalling. Paper discusses also the influence of cold rim that forms while testing slab-like element is subjected to one-side heating.
\end{abstract}

\section{Introduction}

Recent achievements in concrete mix design have led to new types of concretes which, besides an increased mechanical performance, have also shown enhanced behaviour when exposed to harsh environment conditions. The concrete properties improvement is obtained by reducing the water cement ratio and application of pozzolanic materials. However, when exposed to high temperature those dense materials may be prone to explosive spalling when exposed to high temperature. The sensitivity towards spalling of concrete is investigated by numerous research teams, nevertheless it is until now not fully understood phenomenon and more research is needed to predict risk of spalling. One of the issues that seems to be of particular importance is the question if spalling is a material property or spalling propensity is governed by structural effects?

There is a wide range of factors that may induce spalling among which we can distinguish both mechanical and physical ones. Since concrete is a composite material, in which dispersed phase is represented by aggregate and continuous one by cement paste, both aggregate and cement paste may have an influence on propensity of spalling. It is already known that aggregates and moisture play an important role in the behaviour of concrete during fire [1-7]. However, the concrete structures, ex. tunnels, off-shore platforms, nuclear power plant concrete structures, work in different conditions (curing, load, size, environment, etc.), and each of these conditions may also have a great impact on the thermal stability of concrete.

\footnotetext{
*Corresponding author: kmroz@pk.edu.pl
} 
Numerous experimental tests results can be found in the literature [8-16]. All attempting to investigate the fire spalling phenomenon by identifying different parameters that may enhance spalling risk, such as the mix composition, the heating scenario, the initial water content and the geometry of specimen or mechanical boundary conditions. Unfortunately, the influence of specific spalling parameters is difficult to assess and to compare with others due to differences in the testing procedures.

While testing unloaded slab-like elements subjected to one-side heating, tested slab specimen is generally placed horizontally on the top of a furnace. Concrete element lies on the furnace edges, which provide an insulation to fire load. As a result, the unheated part of the tested material does not experience thermal expansion and hence limits the thermal expansion of the heated central part of specimen. Therefore, the cold rim of specimen creates a kind of restraint to thermal expansion of the inner part of the concrete slab and contribute to development of compressive stresses in heated part.

High compressive stresses, caused by restraint to thermal expansion develop when the rate of heating is such high that the stresses cannot be relieved by creep quickly enough [17]. The importance of cold rim presence was discussed in [18]. While testing a slab subjected to central heating, the spalling events stopped as soon as the internal cracks of unheated part were developed [18].

In order to facilitate the comparison of results obtained within fire concrete spalling tests a multiparameter assessment has been carried out with the use of unified procedures for seven different concrete mixes. The objective of presented research was to identify most significant parameters that are believed to induce spalling in concrete and investigate them within unified research procedures.

\section{Tested materials}

\subsection{Mix composition}

Experimental tests were performed with specimens manufactured with high strength concrete (HSC) of various mix compositions, as indicated in Table 1. The individual compositions are designated by three indicators: type of aggregate / w/c - ratio / cement type.

Within 7 mix compositions, three types of coarse aggregates, namely: basalt (B) crushed aggregate, granite $(\mathrm{G})$ crushed aggregate and riverbed gravel $(\mathrm{O})$ were used in order to study the influence of aggregate nature on fire spalling propensity.

Also the effect of presence of Portland cement clinker was observed by fabricating concrete by use of two types of cement: CEM I 42.5 and CEM III/A 42,5 N for basalt concrete with $w / c$ ratio of 0.30 .

Finally, the influence of water to cement ratio is investigated by considering three levels of $\mathrm{w} / \mathrm{c}=0.30,0.45$ and 0.60 for riverbed gravel concrete being manufactured with Portland cement CEM I $42.5 \mathrm{R}$.

It shall be emphasized that all tested compositions have the same content of cement paste and mortar, which facilitates the comparison of particular results.

\subsection{Production and curing of test specimen}

The slabs $(1.2 \times 1.0 \times 0.3 \mathrm{~m})$ and laboratory testing specimen of standard size were produced with the aforementioned concrete mixtures without reinforcement.

Directly after casting, all the test specimens were stored in moulds for 24 hours. Subsequently, concrete is protected from water evaporation by covering it with plastic lids for next 7 days. After demoulding, all the specimens were stored in air-drying conditions: 
temperature of $20 \pm 5{ }^{\circ} \mathrm{C}$ and relative humidity of $50 \pm 5 \%$. The reference test and test concerning fire properties were carried out after 90 days.

Table 1. Mix proportions of the tested concretes

\begin{tabular}{|c|c|c|c|c|c|c|c|c|}
\hline $\mathrm{C}_{\text {Component }}$ Concrete & Unit & 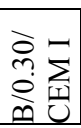 & 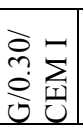 & 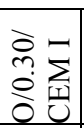 & 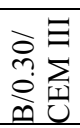 & 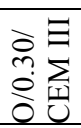 & 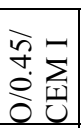 & 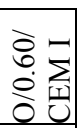 \\
\hline $\begin{array}{l}\text { Cement CEM I 42,5 R } \\
\text { Małogoszcz }\end{array}$ & \multirow{2}{*}{$\mathrm{kg} / \mathrm{m}^{3}$} & \multicolumn{3}{|c|}{482} & \multicolumn{2}{|c|}{-} & 388 & 325 \\
\hline $\begin{array}{l}\text { Cement CEM III/A 42,5 N } \\
\text { Małogoszcz }\end{array}$ & & & - & & \multicolumn{2}{|c|}{482} & \multicolumn{2}{|l|}{ - } \\
\hline Water & $\begin{array}{l}\mathrm{dm}^{3} / \\
\mathrm{m}^{3}\end{array}$ & \multicolumn{5}{|c|}{145} & 175 & 195 \\
\hline $\mathrm{w} / \mathrm{c}$ ratio & - & \multicolumn{5}{|c|}{0.30} & 0.45 & $\begin{array}{c}0.6 \\
0\end{array}$ \\
\hline $\begin{array}{l}\text { Aggregates } \\
\text { Dwudniaki river sand } 0-2 \mathrm{~mm} \\
\text { Dwudniaki gravel } 2-8 \mathrm{~mm} \\
\text { Dwudniaki gravel } 8-16 \mathrm{~mm} \\
\text { Gracze basalt } 2-8 \mathrm{~mm} \\
\text { Gracze basalt } 8-16 \mathrm{~mm} \\
\text { Strzegom granite } 2-8 \mathrm{~mm} \\
\text { Strzegom granite } 8-16 \mathrm{~mm}\end{array}$ & $\begin{array}{l}\mathrm{kg} / \mathrm{m}^{3} \\
\mathrm{~kg} / \mathrm{m}^{3} \\
\mathrm{~kg} / \mathrm{m}^{3} \\
\mathrm{~kg} / \mathrm{m}^{3} \\
\mathrm{~kg} / \mathrm{m}^{3} \\
\mathrm{~kg} / \mathrm{m}^{3} \\
\mathrm{~kg} / \mathrm{m}^{3}\end{array}$ & $\begin{array}{c}662 \\
- \\
- \\
709 \\
648 \\
- \\
- \\
\end{array}$ & $\begin{array}{c}663 \\
- \\
- \\
- \\
- \\
635 \\
580 \\
\end{array}$ & $\begin{array}{l}663 \\
610 \\
558 \\
- \\
- \\
- \\
- \\
\end{array}$ & $\begin{array}{c}662 \\
- \\
- \\
709 \\
648 \\
- \\
- \\
\end{array}$ & $\begin{array}{l}663 \\
610 \\
558 \\
- \\
- \\
- \\
- \\
\end{array}$ & $\begin{array}{l}663 \\
610 \\
558 \\
- \\
- \\
- \\
- \\
\end{array}$ & $\begin{array}{l}663 \\
610 \\
558 \\
- \\
- \\
- \\
- \\
\end{array}$ \\
\hline $\begin{array}{l}\text { Admixtures: } \\
\text { plastyfier BASF BV } 18 \\
\text { superplastyfier BASF SKY } 591\end{array}$ & $\begin{array}{l}\% \mathrm{mc} \\
\% \mathrm{mc}\end{array}$ & $\begin{array}{l}0.90 \\
2.20\end{array}$ & $\begin{array}{l}0.90 \\
2.20\end{array}$ & $\begin{array}{l}0.90 \\
2.10\end{array}$ & $\begin{array}{l}0.90 \\
2.35\end{array}$ & $\begin{array}{l}0.90 \\
2.35\end{array}$ & $\begin{array}{c}0.80 \\
-\end{array}$ & $\begin{array}{c}0.3 \\
0 \\
-\end{array}$ \\
\hline $\begin{array}{l}\text { Content: } \\
\text { Cement paste } \\
\text { Mortar }\end{array}$ & $\begin{array}{l}\mathrm{dm}^{3} / \\
\mathrm{m}^{3} \\
\mathrm{dm}^{3} / \\
\mathrm{m}^{3}\end{array}$ & & & & $\begin{array}{l}300 \\
550\end{array}$ & & & \\
\hline
\end{tabular}

\subsection{Material properties}

The reference properties of manufactured concretes were determined 90 days after casting and curing in air-drying conditions. Physical (density, water content, gas permeability (Cembureau method)) and mechanical properties (compressive strength, splitting tensile strength, modulus of elasticity) are tested using standard concrete specimens. The obtained values for reference properties are presented in Table 2 .

Thanks to the diversity of mix compositions, an evident spread of the obtained characteristic values of physical and mechanical properties can be noticed within tested concretes. Therefore, it is expected to observe different spalling propensity for the individual tests.

Table 2. Mean values of reference properties of tested concretes

\begin{tabular}{|c|c|c|c|c|c|c|c|c|}
\hline Property & Unit & 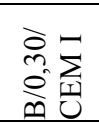 & $\begin{array}{l}0 \\
0 \\
0 \\
0 \\
0\end{array}$ & 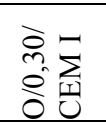 & 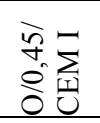 & 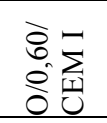 & 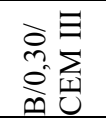 & 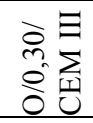 \\
\hline Density & $\mathrm{kg} / \mathrm{m}^{3}$ & 2558.8 & 2376.7 & 2300.7 & 2268.6 & 2177.4 & 2533.2 & 2315.6 \\
\hline Water content & $\%$ & 2.6 & 2.4 & 2.3 & 2.2 & 2.3 & 2.7 & 2.8 \\
\hline Permeability & $\mathrm{m}^{2}$ & $\begin{array}{l}7.00 \\
\text { E-18 }\end{array}$ & $\begin{array}{l}2.58 \\
\text { E-17 }\end{array}$ & $\begin{array}{l}1.20 \\
\text { E- } 17\end{array}$ & $\begin{array}{l}3.39 \\
\text { E-17 }\end{array}$ & $\begin{array}{l}2.22 \\
\text { E- } 16\end{array}$ & $\begin{array}{l}5.23 \\
\text { E-18 }\end{array}$ & $\begin{array}{l}9.96 \\
\text { E-18 }\end{array}$ \\
\hline $\begin{array}{l}\text { Compressive } \\
\text { strength }\end{array}$ & $\mathrm{MPa}$ & 84.9 & 73.3 & 77.0 & 64.4 & 51.5 & 96.2 & 87.4 \\
\hline
\end{tabular}




\begin{tabular}{|c|c|c|c|c|c|c|c|c|}
\hline $\begin{array}{c}\text { Spliting tensile } \\
\text { strength }\end{array}$ & $\mathrm{MPa}$ & 6.2 & 4.9 & 6.0 & 4.7 & 4.0 & 6.9 & 5.6 \\
\hline Elastic modulus & $\mathrm{GPa}$ & 44.4 & 30.6 & 29.7 & 27.3 & 24.7 & 48.9 & 30.9 \\
\hline
\end{tabular}

\section{Heating and testing procedure}

The slab is placed horizontally on chamber of the DRAGON laboratory furnace. During the fire test, the slab is subjected to one side heating for 120 minutes by ISO 834 fire scenario from the bottom with the use of a $140 \mathrm{~kW}$ gas burner.

The specimen is freely supported by thermally insulated furnace external walls of 0.125 $\mathrm{m}$ in thickness. As a result, the directly exposed surface has an area of $0.95 \times 0.75 \mathrm{~m}$ and the unheated support may work as cold rim and limit the thermal dilation of heated part. Slab is tested under unloaded conditions.

During the test, the temperature $(T)$ is measured near to the heated surface with a plate thermocouple and in the concrete at different depths $(1 \mathrm{~cm}$ to $22 \mathrm{~cm}$ with spacing of $3 \mathrm{~cm})$ by aid of of thermocouples type $\mathrm{K}$ placed in the specimen before casting. Additionally, the time of spalling initiation $\left(t_{0}\right)$ and its end $\left(t_{1}\right)$ are reported.

After heating, the specimens could freely cooled down. Before taking measurements, the fire damaged surface has not been brushed or cleaned. The spalling propensity is assessed by investigation of fire-exposed area. Measurements of spalling depth are taken manually with spacing of $25 \mathrm{~mm}$. Having the data gathered, the maximum spalling depth $\left(d_{\max }\right)$, volume of spalled material $\left(V_{s}\right)$ and volume $V_{s}$ related to the initial volume of slab $\left(V_{r e l}\right)$ have been derived.

\section{Test results}

\subsection{Observations during heating}

Fire spalling events: if a fire spalling event occurs, the time of its initiation and its duration is listed. In six of seven slabs, fire spalling was observed. The concrete that did not experience an explosive behaviour was the one being manufactured with riverbed gravel aggregate, $\mathrm{w} / \mathrm{c}$ ratio equal 0.6 and cement type CEM I $42.5 \mathrm{R}$, designated as O/0.6/CEMI. In the remaining six concretes, the popcorn-like spalling started between 1st and 4th minute of fire exposure, when temperature of surface was between $350{ }^{\circ} \mathrm{C}$ and $550{ }^{\circ} \mathrm{C}$. Afterwards, between 5 th and 7 th minute of testing, when temperature of surface was ca. $500{ }^{\circ} \mathrm{C}-600{ }^{\circ} \mathrm{C}$, the explosive behaviour occurs with large pieces spalled off the surface, Figure 1. Spalling continued for 30 - 40 minutes and its duration did not change significantly for concretes of different compositions.
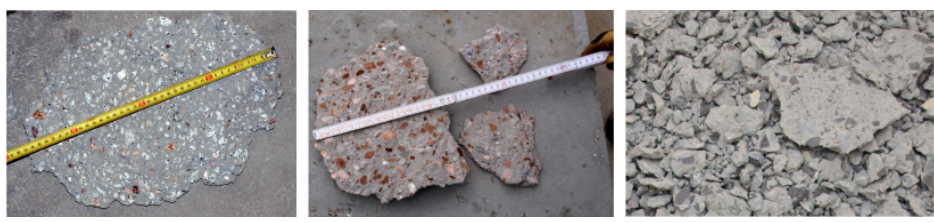

Fig. 1. Spalled pieces of concrete, from left: G/0.3/CEM I, O/0.45/CEM I, B/0.3/CEM I.

Lateral cracks: During fire tests the propagation of lateral cracks in unheated rim took place. It was observed that the lateral cracks formation (Figure 2) effectively allowed to release a large amount of water vapor during heating, thus reducing gas pore pressure and limiting the spalling. In the tested slabs, two to three lateral cracks appeared between 5 th and 
15th minute after start of fire exposure. In most cases, the spalling stopped when two or three lateral cracks became visible at each side of the tested element. It has been noticed that greater spalling intensity corresponds to more lateral cracking, irrespective of initial moisture content of the concrete. In case of specimen O/0.6/CEMI that did not spall, one lateral crack of significant width $(0.5 \mathrm{~mm}$ to $2.0 \mathrm{~mm})$ has been formed after ca. 6 minutes of fire exposure and intense release of water vapor has been observed for ca. 30 minutes.

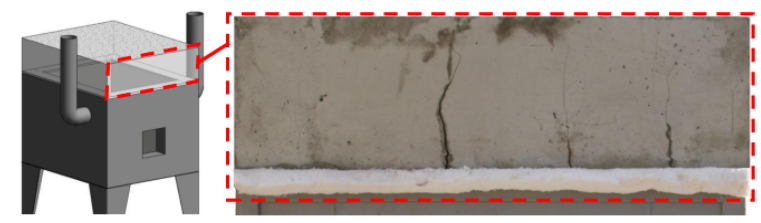

Fig. 2. External side of specimen of O/0.45/CEMI during heating: lateral cracking and release of water vapor.

\subsection{Post-fire investigations}

After cooling the specimens down, the slab were removed from the furnace and the post-fire investigations took place.

No post-cooling sloughing off was observed, probably due to lack of aggregate of calcareous nature in the compared mixes. The post-fire observations consist of the following determination:

- Spalling topography: post-cooling investigations of tested slabs consisted in measurements of spalling depth at grid with mesh of $25 \mathrm{~mm}$ and visual inspections of cracking of the unheated part of specimen (cold rim). Spalling topography was prepared in the same scale for all tested concretes. Blue color correspond to $0 \mathrm{~mm}$ of spalling depth while red one to $65 \mathrm{~mm}$, which was the maximum depth measured within all the specimens. The maps of spalling topography along with the corresponding measurements of maximum depth, volume and relative volume of spalling are presented in Figure 3 with the increasing order. It has been noticed that concretes made with riverbed aggregate are generally more susceptible to spall, and the measured maximum depth and volume of spalled material are greater in comparison to concretes made with basalt and granite aggregates.

- Cement type effect: The effect of cement type on spalling has been analyzed. Investigated concretes were manufactured with cement types CEM I and CEM III. It was observed that concretes made with CEM I had greater permeability and lower compressive strength in comparison to those made with CEM III. However, more permeable concretes of lower strength made with CEM I indicated greater volume and depth of spalling, Figure 4a.

- Water / cement ratio effect: the effect of w/c ratio has been analysed by comparison of measured maximum spalling depth for concretes made with riverbed aggregate and cement type CEM I. For manufacturing concretes with w/c ratio of $0.3,0.45$ and 0.6 , different amount of water has been used: $145 \mathrm{dm}^{3} / \mathrm{m}^{3}, 175 \mathrm{dm}^{3} / \mathrm{m}^{3}$ and $195 \mathrm{dm}^{3} /$ $\mathrm{m}^{3}$, respectively. As a result, concrete with less amount of water, presents higher density and compressive strength and lower permeability. The experimental results show that for concrete with w/c ratio of 0.6 spalling does not occur. However, for concretes of $\mathrm{w} / \mathrm{c}=0.45$ and 0.3 spalling takes place and its depth and volume is greater for more dense and less permeable material, Figure $4 \mathrm{~b}$. 


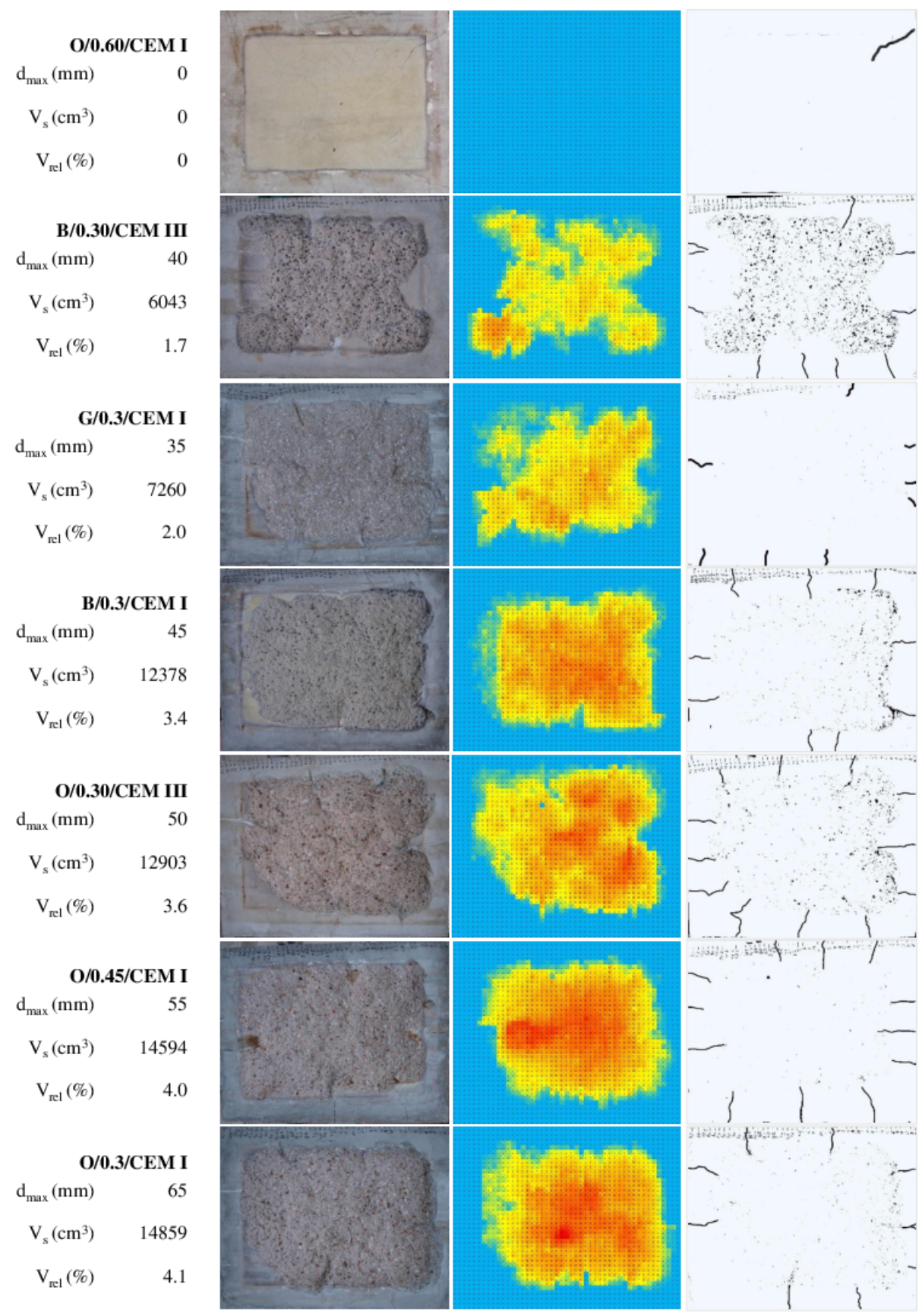

Fig. 3. Spalling observations, from left: measured data, picture of slab after test, spalling topography (blue $=0 \mathrm{~mm}$, red $=65 \mathrm{~mm}$ ), cracking of cold rim. 


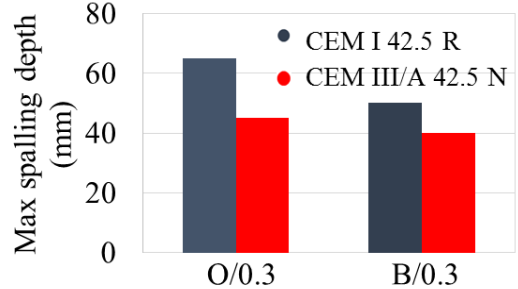

a)

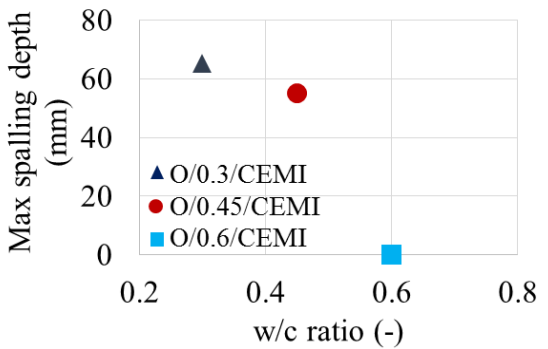

b) w/c ratio (-)

Fig. 4. Effect of a) cement type, b) water / cement ratio on maximum spalling depth.

\section{Conclusions}

The presented results have been gathered with concrete specimens exposed to one side heating in the fire testing DRAGON setup. Research program includes test of seven concretes of different mix proportions. Within all designed concrete mixture the same content of cement paste and mortar has been assumed. Therefore, the comparison of the influence of individual factors on concrete susceptibility to spalling is more evident.

On the basis of gathered results, following conclusions and observations can be stated:

- One of seven concretes, designated as O/0.6/CEMIII did not indicate spalling. Due to significantly greater amount of water used for production $\left(195 \mathrm{dm}^{3} / \mathrm{m}^{3}\right)$ in comparison to the other six concretes $\left(145-175 \mathrm{dm}^{3} / \mathrm{m}^{3}\right)$, its initial properties (density, permeability, strength) greatly stand apart the results obtained for other compositions.

- For remaining six concretes, spalling occurred when the temperature of surface was between $350{ }^{\circ} \mathrm{C}$ and $550{ }^{\circ} \mathrm{C}$. When temperature increased to ca. $500{ }^{\circ} \mathrm{C}-600{ }^{\circ} \mathrm{C}$, the explosive behaviour occurred with large pieces spalled off the surface.

- Within spalled specimens, the greatest value of spalling depth was measured as 65 $\mathrm{mm}$ (for concrete O/0.3/CEM I). It corresponded to $22 \%$ of the entire thickness of tested specimen.

- Significantly more intense spalling was observed for concretes made with riverbed gravel aggregate. Basalt and granite concretes spalled less of ca. $50 \%$ in volume in average.

- More dense and less permeable concretes are more prone to spall. However, the results show that such conclusion holds only for concretes made with aggregate of the same nature and with the same type of cement. While comparing the results for all the tested concretes, such conclusion seems not to be such evident.

- It has been shown that spalling is more likely to occur for concrete made with cement type CEM I 42.5 R than for CEM III $42.5 \mathrm{~N}$. It is despite greater permeability of concrete made with CEM I than CEM III. It indicates that the initial permeability of concrete may not be a decisive factor inducing spalling.

- During heating, two to three lateral cracks occurred in unheated part of concrete specimens, irrespective of spalling intensity. However, it seems that greater spalling volume corresponds to lateral cracks of greater width. It is probably due to more severe spalling and therefore higher release of water vapor is needed.

- Observations of development of lateral cracks during heating confirm that the unheated part of specimen work as a cold rim and limits thermal dilation of concrete.

- In case of specimen O/0.6/CEMI that did not spall, one lateral crack of significant $(0.5$ $\mathrm{mm}$ to $2.0 \mathrm{~mm}$ ) width has created and intense release of water vapor has been 
observed. It confirms that unheated part of concrete retraints the thermal dilation of heated one and experience tension in a transverse plane.

Lack of significant differences in spalling mechanisms within the tested concretes provides the presumptions that material properties may not be a decisive factors influencing the behavior of concrete element under fire attack. In other words, it seems that most of High Performance Concretes is prone to spall, regardless of its properties. Therefore, further comprehensive experimental studies on the effect of cold rim and other structural aspects are highly needed in order to clarify the effect of boundary conditions on spalling severity.

This work was supported by the Polish National Science Centre [grant number N N506 045040].

\section{References}

1. D.R. Lankard, D.L. Birkimer, F.F. Fondriest, M.J. Snyder, Temperature and Concrete, 59-102, (ACI, Detroit, 1971)

2. R. Jansson, L. Boström, 1st International Workshop on Concrete Spalling due to Fire Exposure, 120-129 (2009)

3. I. Netinger, I. Kesegic, I. Guljas, Fire Saf. J. 46, 425-430 (2011)

4. J. Mindeguia, P. Pimienta, C. La Borderie, Eur. J. Environ. Civ. Eng. 16, 236-253 (2012)

5. R. Jansson, L. Boström, MATEC Web Conf. 6, 3003 (2013)

6. K. Krzemień, P. Pimienta, N. Pinoteau, I. Hager, 4th International Workshop on Concrete Spalling due to Fire Exposure, 165-176 (2015)

7. I. Hager, T. Tracz, J. Śliwiński, K. Krzemień, Fire Mater. 40, 668-682 (2016)

8. R. Jansson, Fire spalling of concrete: theoretical and experimental studies, 154 (KTH, Stockholm, 2013)

9. K. Krzemień, I. Hager, Procedia Eng. 108, 285-292 (2015)

10. H. Carré, P. Pimienta, C. La Borderie, F. Pereira, J.C. Mindeguia, MATEC Web Conf. 6, 1007 (2013)

11. I. Hager, P. Pimienta, Workshop Fire Design of Concretes: What now? What next?, (2004)

12. J.C. Mindeguia, Contribution Expérimentale A La Compréhension Des Risques D'instabilité Thermique Des Bétons, (Universitè de Pau et des Pays de l'adour, 2009)

13. L. Boström, R. Jansson, Self-compacting concrete exposed to fire, (SP, Borås, 2008)

14. R. Felicetti, F. Lo Monte, P. Pimienta, Cem. Concr. Res. 94, 13-23 (2017)

15. S. Huismann, F. Weise, B. Meng, U. Schneider, Mater. Struct. Constr. 45, 793-801 (2012)

16. W. Lindlbauer, M. Zeiml, A. Heel, W. Kusterle, Fire resistance of fiber-reinforced, reinforced, and prestressed concrete (in German) (Straßenforschung 3.269, Vienna, 2004)

17. G.A. Khoury, Spalling Review (Fire Safety Design, 2005)

18. K.D. Hertz, Fire Saf. J. 38, 103-116 (2003)

19. EN 1992-1-2 (2004) 